\title{
A Gender Integrative Conceptualization of Entrepreneurship
}

Susan Clark Muntean

Banu Özkazanç-Pan

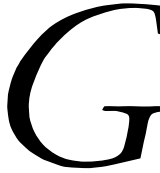

wided by feminist perspectives, we critique existing approaches to the study of women's entrepreneurship on epistemological grounds and suggest that the entrepreneurship field needs to recognize gendered assumptions in theorizing. Deploying a feminist framework, we suggest that understanding the "gender gap" in entrepreneurship requires focus on institutional and structural barriers women entrepreneurs face. Existing studies of women entrepreneurs often compare women with men without considering how gender and gender relations impact the very concepts and ideas of entrepreneurship. We propose, therefore, a conceptualization of entrepreneurship that illuminates gender bias and calls attention to the interrelated individual, institutional, and structural barriers in the entrepreneurial process that arrive out of societal and cultural gender norms. Through praxis or engaged practice, we redirect scholarship in the entrepreneurship field, while proposing ways that can promote gender equality in entrepreneurial activities. In all, our gender integrative conceptualization of entrepreneurship contributes to the entrepreneurship field by recognizing and addressing a more expansive realm of influential factors within the entrepreneurial ecosystem that have previously been researched separately.

Keywords: women entrepreneurs; gender; feminist; ecosystem

In the entrepreneurship field, almost all of the scholarly work on gender or related to female entrepreneurs has been categorized as "women's entrepreneurship" and relegated to a subfield or niche status. In recent years, there has been a call to address the lack of conceptual papers and theory-building in this subfield (De Bruin et al., 2006). As Greene et al. (2003) point out in a meta-analysis of the literature, 94 percent of papers in the subfield are empirical and lack a rigorous theoretical framework, while those that apply an existing theory have gendered ontological and epistemological assumptions. To address these concerns, this paper advances feminist frameworks for the study of entrepreneurship and calls for critical analyses of gender to be integrated fully into the entrepreneurship field.

Drawing on multiple strands of feminist theory, we first critique existing approaches to the study of "women's entrepreneurship," while suggesting that a gender integrated conceptualization of entrepreneurship that attributes gender rightly to both men and women is necessary. We suggest that "women's entrepreneurship" research focuses unproductively on biological sex and is thus unable to offer solutions to the continued marginalization women face in entrepreneurship activities. To this end, we propose redirecting entrepreneurship research in a way that recognizes the importance of gender in relation to the individual, institutional, structural, and cultural factors integral to doing entrepreneurship. Furthermore, we argue that gender equality in entrepreneurial ecosystems will only be possible when the broader entrepreneurship field recognizes the ways in which gender informs all entrepreneurial activities and environments.

Throughout this article we apply multiple feminist theoretical lenses to demonstrate the ways in which macro-level factors influence entrepreneurial processes and decision-making at each stage. Such an integrated approach is rarely found in the literature, although there have been scholars who have addressed the ways in which structural mechanisms relate to women's entrepreneurial processes (Ahl, 2002; Bourne, 2006; De Bruin et al., 2007; Brush and Edelman, 2000; Thebaud, 2010). Expanding on the work of these scholars, we suggest that societal-level attitudes, beliefs and expectations regarding gender roles both in the home and in the marketplace are important, as these shape men and women's selfperceptions and impact resources available to them for starting growth-oriented firms (Anna et al., 2000; De Bruin et al., 2007). Yet understanding these normative gender norms and roles is necessary but not sufficient to change institutional and structural mechanisms that maintain or exacerbate gendered outcomes in entrepreneurship for women and men (Ahl and Nelson, 2010).

As such, while acknowledging that the entrepreneurial discourse and the entrepreneurial process itself are gendered, we depart from much of the work in "women's entrepreneurship" that contrasts women founders and the performance of womenfounded businesses with men founders and menfounded businesses (Ahl, 2006; Bird and Brush, 2002; Mirchandani, 1999; Robb and Watson, 2012; Watson, 2002). Beyond our feminist critique of the field of women's entrepreneurship, we engage in feminist praxis to discuss "the way the world could 
and should be" in order to transform entrepreneurial ecosystems to support male and female entrepreneurs and their businesses equally. We understand praxis to be the "processes through which theory and practice become deeply interwoven with one another" (i.e., Freire, 1970/1990) and feminist praxis a further understanding of such processes whereby the "intellectual and the political" become mutually constituted in the quest for gender equality, social justice, and change (Nagar and Swarr, 2010: 6; also Stanley, 2013). This engaged approach recognizes the political aspects in the intellectual endeavors to conceptualize entrepreneurship such that efforts to theorize and research entrepreneurship are understood through the lens of gender and with the aim of gender equality. As such, calls for gender equality reflect an intellectual recognition of the ways in which gender is an organizing principle in entrepreneurship research and practice and a political perspective that recognizes women's marginalization from theory and research in the field. Through our feminist frameworks and praxis, we consider the full range of support entrepreneurs need from a broad range of resource providers and how to make these more accessible in order to transform the ecosystem to be more inclusive (Baughn et al., 2006; Langowitz and Minniti, 2007). Closing the gender gap may encourage the founding and flourishing of enterprises that are more innovative, sustainable, and rewarding places to work. To understand how these changes may take shape, we first discuss feminist scholarship within the context of the entrepreneurship field.

\section{Feminist Approaches to the Study of Entrepreneurship}

At the intersections of feminist research and the entrepreneurship field, a small number of scholars have adopted an explicitly feminist perspective to the study of entrepreneurship (Ahl, 2004; Ahl and Marlow, 2012; Bourne, 2010; Calás, Smircich and Bourne, 2007; Özkazanç-Pan, 2014). Within this context, feminist theorizing uncovers where stereotypes and "subjective perceptual variables" come from, to enrich our understanding of how these "exert a crucial influence on women's entrepreneurial propensity and can account for much of the difference in entrepreneurial activity between the sexes" (Jennings and Brush, 2013: 685; see also Gupta et al., 2008, 2009; Gupta, Goktan and Gunay; 2014; Gupta and Turban, 2012; Langowitz and Minniti, 2007). For example, Sullivan and Meek (2012) highlight how the societal attribution of gender roles and gendered socialization processes create unique barriers to entry for women, such as unequal access to assets, skewed educational focus areas, and gendered "daily life activity expectations amongst the sexes". Like a "perfect storm," these multifaceted factors magnify each other such that they generate a formidable glass ceiling in the professions (Antony, 2012) and in entrepreneurship. Given these barriers, women have lower expectancy, instrumentality, and valence (Vroom, 1964) with respect to entrepreneurial activities and these are manifested in gender differences at each stage of entrepreneuring (i.e., the enactment of entrepreneurship), including motivation, opportunity recognition, acquisition of resources, and entrepreneurial performance/venture success (Sullivan and Meek, 2012: 428-9; Baron and Henry, 2011).

Emergent feminist voices in the "women's entrepreneurship" subfield deliver highly relevant material for theory building and empirical analysis for the broader entrepreneurship arena. For example, in a comprehensive meta-analysis of the women's entrepreneurship field, Jennings and Brush (2013) identify four substantive contributions for the broader field of entrepreneurship arriving out of feminist research: "1) entrepreneurship is a gendered phenomenon, 2) entrepreneurial activity is embedded in families, 3) entrepreneurial activity can result from necessity as well as opportunity, and 4) entrepreneurs pursue goals beyond economic gain" (681). Along the same lines, Ahl and Marlow (2012) suggest abandonment of the male-female binary and adoption of feminist perspectives for application to the entire field of entrepreneurship. Expanding on these feminist contributions to the entrepreneurship field, we outline varieties of feminism and related work in the next section. Following this step, we deploy feminist critique to the field of "women's entrepreneurship" in order to question assumptions and to provide new direction for research.

\section{Varieties of Feminism}

Liberal Feminism. Liberal feminists seek equal opportunity for women and assume that the removal of institutional and legal barriers will result in women founders achieving equitable entrepreneurial outcomes with male founders (Butler, 2003; Greer et al., 2003). Although liberal feminism assumes men and women are essentially the same, critics have pointed out that the male remains the unspoken, implicit norm as an entrepreneur (Ahl, 2002; Smircich and Calás, 1992) . Further, liberal feminist perspectives tend to ignore gender inequities in home and family labor (Greer et al., 2003).

Socialist Feminism. Socialist feminists acknowledge the life-long socialization processes that shape women to be equal, but different than men in the ways in which they view the world 
(Carter and Williams, 2003; De'Tienne and Chandler, 2007; Fischer et al., 1993). Given the strength of cultural experiences that shape the way women entrepreneurs view their roles in society and their chances of success in the marketplace, socialist feminists view liberal feminists' goals of equality of opportunity based on the assumed androgynous entrepreneur to be misguided (Carter and Williams, 2003). It is important to note that socialist feminism does not view women's socialized experiences as inferior, but rather different. Consequently, the environment should acknowledge and embrace such gender role differences instead of dismissing or removing them. Embracing a socialist feminist stance means that when there are gender differences (biological, socially constructed, or otherwise), unequal economic power relations associated with such differences are acknowledged.

Marxist Feminism. Marxist feminists express the need for the socialization of both child care and domestic/household work in addition to full equality in the paid labor force (Greer et al., 2003; see also Bourne, 2006; Eddleston and Powell, 2012). While contributing an important variable in addressing economic inequality along gender lines, Marxist feminist approaches are limited in relation to theories of entrepreneurship because the focus is on paid labor, with the assumption of being hired by an organization rather than self-employment. Although there are exceptions, when entrepreneurship researchers point out the relationship between the unequal distribution of labor in the household, on the one hand, and the capacity for entrepreneurial activity, on the other, the traditional Marxist goals of developing working-class consciousness becomes problematic for entrepreneurship (Greer et al., 2003). The goals of Marxist feminists may appear to be at odds with entrepreneurial goals, which assume and generally accept the status quo and normative superiority of a market-based capitalist system versus a Marxistbased economic system such as communism or socialism (Barrett, 2014). Moreover, the tension-filled relationship between Marxist economic theories that do not acknowledge women's productive capacity with the agency afforded them under feminist lenses offers a complex array of possibilities for rethinking various forms of economic arrangements and entrepreneurship activities. To this end, Marxist feminist approaches can offer insights around consciousnessraising around gendered entrepreneurship activities (see also Calás and Smircich, 2006 for an overview of possibilities).

Radical Feminism. Radical feminists suggest that men and women are inherently different, and fur- ther, that men have exploited these differences to their own hegemonic advantage (Butler, 2003). Radical feminism rejects the socialized norms for overly favoring the dominant masculine hegemony, and makes explicit that adoption of feminist organizations and approaches is its goal. In the dominantly masculine entrepreneurial ecosystem, pro-female and overtly pro-feminist organizations and institutions are rare. However, there is an emerging movement toward launching female-only incubators, accelerator programs, educational workshops, business plan pitch contests, angel investor funds, and networks, which aligns well with radical feminist perspectives (Clark Muntean, and ÖzkazançPan, 2014).

Poststructuralist Feminism. Discourse analysis by feminist discursive theorists illuminate how the discussion of entrepreneurship assumes the masculine ideal type, as it is based on the male mentality, experience, imagery, and perceptual lens (Achtenhagen and Welter, 2007; De Bruin et al., 2006; Bruni et al., 2004). Importantly, these scholars turn the lens back on the researcher and discipline, noting how the very research practices we engage in, even if intending to close the gender gap, may end up perpetuating the dominant masculine model by reproducing social reality (Ahl, 2002, 2006).

Guided by these various different feminist frameworks, we deploy them to question underlying epistemological assumptions in the field of "women's entrepreneurship" research in the next section.

\section{Feminist Critique of Existing Literature on Women's Entrepreneurship}

The focus of our critique is the set of literature that claims awareness or sensitivity to women in entrepreneurship. That is, despite being focused on "women entrepreneurs," our feminist critique uncovers epistemological assumptions that are problematic in this literature with regard to gender norms and expectations. We suggest that these assumptions can be particularly detrimental for challenging and changing existing behaviors, structures, and institutions that may be perpetuating gender inequality in entrepreneurship. First, the level of analysis and proposed solutions are largely limited to individual entrepreneurs, or women as a class of entrepreneurs that fall short of the male ideal in some respect (Ahl and Marlow, 2012, Ahl, 2006). Second, the literature lacks rigorous theoretical and conceptual development, and finally, existing approaches lack a critical lens as they do not directly challenge or provide sufficient possibilities for chang- 
ing institutional and structural barriers. We develop each of these critiques in turn in this section.

\section{Individualistic Approach: Gender as Biology}

Meta-analyses of the "women's entrepreneurship" subfield reveal an overarching individualistic approach to the study of women business owners, and even when society's cultural and institutional barriers are acknowledged, the recommendations imply individual entrepreneurs or women as a class need to "fix" themselves to adapt to the barriers and navigate around bias in the system (De Bruin et al., 2007; Sullivan and Meek, 2012). The entrepreneurial context-the historical, societal, and structural factors that influence the entire entrepreneurial process-is largely ignored in the study of women entrepreneurs (Ahl, 2006; Chell and Baines, 1998). Publications in the top entrepreneurship journals rarely take a critical approach to investigating the structural barriers and making direct recommendations for cultural, social, political, and institutional change to remove them. Further, the literature is silent as to explicit interventions and public policies necessary to level the playing field. In a study of 435 academic articles, Brush and Edelman (2000) found only two studies (Servon, 1996; Sonfield, n.d.) that examine the governmental and public policy issues in the entrepreneurial environment that influence women's entrepreneurship. While efforts are being made to study the gender gap in access to equity finance in academia (via the Diana Project, for example), only recently have scholars begun to address the massive gender gap in the pipeline toward equity finance, such as that found in business incubators, many of which are indirectly or directly subsidized with taxpayer dollars (Clark Muntean, and Özkazanç-Pan, 2014; Marlow and McAdam, 2013).

Moreover, the individual approach assumes that biological sex and gender are equated in a way that gender is only considered in respect to the study of women entrepreneurs. As such, male entrepreneurs are the unvoiced norm against which women's entrepreneurial ideas, values, practices, and processes are gauged. By engaging in such gender differentiation, there is little discussion or ability to see the very notions and practices of entrepreneurship as already being gendered. In other words, the presumed gender neutrality of entrepreneurship is rarely noted or called into question, nor is there a critical lens applied toward the gendered institutional and cultural factors that structure the context surrounding entrepreneurial activities. Ironically, these factors impact entrepreneurial outcomes for both women and men (Thebaud, 2010).

\section{Lack of a Rigorous Theoretical Basis}

These points lead us to question further the epistemological assumptions of the entrepreneurship field. Within this context, the subfield of "women's entrepreneurship" is comprised largely of empirical studies, mostly descriptive, that engage in the study of only women business owners or that use gender as a "dummy" binary variable in comparing women business owners to men business owners (Greene et al., 2003). By offering comparisons between men and women entrepreneurs, the assumption is one of "equality, but difference" rather than a concern or ability to see how inequalities are taking place during entrepreneurial processes. Robust theorizing about gender and entrepreneurship is rare, and the field is exclusively focused on women, as if men had no gender. Further, theories of entrepreneurship were largely developed based on studies of male entrepreneurs, historically by researchers who were almost exclusively male, and were based on theories generated predominately by men in the study of mostly men (Bird and Brush, 2002; De Bruin et al., 2006; Greer et al., 2003; Hurley, 1999). Thus, women's experiences have, from the onset of the development of the entrepreneurship as a field of inquiry, either been marginalized or are altogether missing from how entrepreneurs and entrepreneurship are generally understood. In addition, in the mainstream field of entrepreneurship, the entrepreneur is not analyzed for his position as a man, or his experience as a male, nor assessed for what privileges (or disadvantages) his gender bring to entrepreneuring.

\section{Lack of a Critical Lens to the Structural Issues}

Even scholarship that ventures beyond the mainstream individualistic approach to the study of women entrepreneurs in acknowledging the meso (institutional) and macro (societal/cultural/ structural) environments inadvertently may perpetuate gender disadvantage by not problematizing the status quo assumptions, social norms, and structural barriers present in the entrepreneurial ecosystem. For example, Brush et al. (2009) in creating a "genderaware framework for women's entrepreneurship" adds " $\mathrm{M}$ " to a conceptual model of women's entrepreneurship to account for motherhood and the socially constructed gender norms found in their meso and macro environments. While the acknowledgement of women's disadvantaged position in the practice of entrepreneurship is a first step, placing the care of children as a "motherhood" issue rather than a "parental" issue for both male and female entrepreneurs appears to solidify these societal norms instead of challenging them. By adopting the metaphor of "motherhood" to represent the household and family context that impacts entrepreneurial 
capacity, motivations and outcomes for women entrepreneurs, but not men entrepreneurs, the authors inadvertently condone socially constructed gender role norms that demand more dedication in the home from women relative to men. Traditional gender roles in which women constitute an unpaid and taken-for-granted resource (Gibson-Graham, 1996; Hoskyns and Rai, 2007) benefiting male entrepreneurs remains invisible. Further, the role of male entrepreneurs as fathers, spouses, and household members with responsibilities to others remains silenced in the literature. Women entrepreneurs are wrongly positioned as being unique in their role as parents, when men entrepreneurs are as equally likely to be parents.

This framing also lacks an understanding of how men's entrepreneurial success is built on a foundation of women's unpaid reproductive and unpaid care labor, which enables men to dedicate the time required for entrepreneurial opportunity recognition and entrepreneurial endeavors (see Barker, 2014). Other poorly compensated supporters of these male entrepreneurs include their mothers, hired nannies and babysitters, and housecleaners who are overwhelmingly female (see Cooper, 2000). In all, various women enable the male family member to leave the home for longer hours to work on their business, develop and exploit their networks, and reserve the energy and resources to grow their businesses. The lack of men willing to play this unpaid support role for growth-oriented women entrepreneurs must also factor into the decision calculus why many women entrepreneurs reduce their growth objectives. Thus, scholars need to more carefully analyze the "workfamily balance" motivation individual women express for starting a business as well as any lower growth ambitions.

In many ways, such individual-level manifestation of women's desires and behaviors may very well be based on familial, structural, and cultural constraints placed on them rather than evidence of their lack of desire to start and run high-growth businesses. By not making explicit where the resources come from for male entrepreneurs to thrive, scholarseven if unintentionally or with the opposite intention-solidify and aggravate the systemic economic oppression of women that stems from the appropriation of their labor toward noncompensated and poorly compensated activities. If women are burdened with greater responsibilities with respect to caregiving and housework, this would enable men to found and manage higher growth businesses than women. Thus, gender gaps in the distribution of work in the "private" sphere may explain gender gaps in the "public" sphere, including entrepreneurial activities outside the home.
Our conceptualization of entrepreneurship integrates and makes whole the private and the public realms by acknowledging caregiving and housework as critical to freeing up time for founding, growing, and running businesses for both men and women. This represents a contribution to the entrepreneurship literature, which "hardly mentions family" (Ahl, 2002: 8) and when it does, it does so in relation to women entrepreneurs and never male entrepreneurs.

\section{New Approaches for the Study and Practice of Entrepreneurship}

What is needed is to go beyond description of the way the world is and to propose a new way of redesigning entrepreneurial ecosystems that truly promotes gender equality and supports start-ups by women and men. Status quo gender roles are currently sanctioned by entrepreneurship research, perhaps because everyday societal gender norms promoted through popular culture and media go unchallenged by mainstream entrepreneurship scholars. Although women hold approximately half of the jobs in business leadership and half of all managerial positions (Toegel, 2011), the "ideal-type" entrepreneur, business leader and captain of industry is still decidedly male in the media, case studies, textbooks, and the collective imagination. On the flipside and even well into the 21 st century, women are still more likely to be portrayed as primary caregivers than are men, despite their full entry into the workforce. Yet society is changing in some respects. For example, male business managers, owners, and executives express ever greater work-life conflict along with stress from internalizing the societal gender norm that males be primarily economically responsible for their households (Aumann et al., 2011; Bond et al., 2002).

Indeed, the alternative models for women's entrepreneurship and solutions to gender inequity that scholars have promoted are situated within the gender-biased system. Reading between the lines, we are left with frameworks that assume women are rationally less ambitious, and thus that call for accommodation of their socially constructed responsibilities as primary caregivers (Brush et al., 2009) and acceptance of their greater risk-aversion or personal preferences for smaller sized firms (Robb and Watson, 2012). In addition, proposed solutions stay within the status quo and do not begin to challenge gender bias in the system directly. For example, entrepreneurship scholars have recently suggested that women founders should find males to be on their teams in order to have a better chance of receiving equity funding, rather than solving the bias in the equity financing ecosystem itself (Godwin et al., 
2006). These "solutions" the field provides individual women do nothing to challenge the structural bias in the entrepreneurial institutions themselves. Indeed, growth-oriented entrepreneurial institutions penalize the very presence of women at the helm, even in mixed teams (Roberts and Johnson, 2013). Why, we ask, are the alternative models focused on "fixing the women" or accommodating societal norms that disadvantage them economically relative to men? Further, why aren't empirically supported strengths of women and feminine approaches to new venture creation and management applied to launch a more comprehensive and inclusive model of entrepreneurship? To address these shortcomings, we propose and explain our gender integrative conceptualization of entrepreneurship below.

\section{From Concept to Praxis in Gendering Entrepreneurship}

Following the call by Calás, Smircich and Bourne (2009), we reframe entrepreneurship as a potent avenue for social change by applying an explicitly feminist lens to our analysis of gendered entrepreneurial processes and the gendered entrepreneurial ecosystem. Further, we establish a territory for theories of entrepreneurship that are normative and explicitly pave the way for social change. We view the study and practice of entrepreneurship as an avenue for achieving greater social justice and fairness and as such, can strive for societally beneficial, sustainable outcomes that lead to human flourishing. Based on praxis (i.e., the feminist practice of working toward gender equality and social justice) we call for new directions in entrepreneurship research and practice. In doing so, we call attention to the lack of gender equality arguments in the field of "women's entrepreneurship" and in the top entrepreneurship journals whereby feminist work becomes delegitimized by the gatekeepers in our discipline (Ahl, 2002).

The gender integrative conceptualization that we propose goes beyond simple awareness of gender injustices and inequities, and moves to transform institutions that provide crucial entrepreneurial support that could expand the range of choices for both men and women. We differentiate our approach from the "gender-aware framework" or the "integrated perspective" (see Bird and Brush, 2002; Brush et al., 2009; Buttner, 2001) given newer research that suggests women and men are more similar than different in the way they view their businesses (Ahl, 2002; Chell and Baines, 1998). While we acknowledge the range of feminine and masculine strengths that women and men, respectively, can bring to their enterprises, we also address recent em- pirical findings that problematize the gendering of what it means to be an entrepreneur.

Here we outline interventions that can allow new directions in entrepreneurship theorizing and research. These include rethinking the very foundation of "women's" entrepreneurship and positing the ways in which caregiving labor and responsibility become shared rather than assigned to women. Our suggestions include three interrelated points: rethinking responsibility for caregiving labor, understanding the role of support organizations in addressing gender equality, and moving toward a holistic understanding of entrepreneurship that recognizes the interdependence of the public and private spheres.

To this end, our first intervention removes the "M" for motherhood in the gender-aware/ integrative model of Brush et al. (2009) and replaces it with a "P" for parenthood, making a normative claim that male entrepreneurs as well as partners of female entrepreneurs as coproducers of offspring have equal responsibilities for domestic tasks and caregiving in the household. In doing so, we make visible the previously invisible responsibility of men for caregiving of their children and their homes, as well as making visible the role played by women in the caregiving of the family members and in the homes of male entrepreneurs. Women's unpaid labor has previously been ignored as a critical resource to entrepreneurial success, while at the same time constituting a form of subordination of women as business owners (Ahl, 2002; Goffee and Scase, 1983). By making explicit the opportunity cost of caregiving in relation to venture creation and growth and its collective economic costs, policy makers may be incentivized to invest in high-quality, full-day public educational programs and child care facilities to spur economic growth. Further, this would serve to enable men and women to participate in entrepreneurial activities "on equal terms" (Ahl, 2002: 8).

In practice, particularly in the United States where the political will to subsidize universal daycare is lacking, this equality of responsibility might be implemented immediately in multiple, flexible ways privately, as well as through taking multiple political actions. Domestic and caregiving work might explicitly be shared equally over a lifetime, but allowing time periods in which the female partner might take on more of these responsibilities, and other time periods in which the male partner takes them on; in other words, it accommodates for times when both partners cannot or choose not to take on equal domestic roles. Equal education of both sons and daughters in entrepreneurial endeavors and in caregiving and homemaking as well as the transfor- 
mation of popular culture to reflect progressive, feminist values are long term but pertinent parts of the solution.

Second, addressing the gender gaps in the entrepreneurial support structures and organizations is also a critical component of the solution. Women remain poorly represented in the top echelons of power that hold the ultimate keys to public policy, finance, and entrepreneurial success (e.g., executive suites, boards, banks, venture capital firms, angel investor networks, incubator and accelerator programs, business plan and pitch competition judges, boards of directors and advisors, top corporate law firms, and highest political offices). As long as this institutionalized gender gap remains, gatekeeping activities involving decisions about what is valuable and worthy of time, attention, and investment are likely to remain highly gendered and in favor of men.

We illuminate our approach and compare it to existing gendered conceptualizations in entrepreneurship in Figure 1. Note that we list the negative attributes or gendered stereotypes of men and women entrepreneurs and male-founded and femalefounded businesses in the first two types that we posit should be retired in the field of entrepreneurship. The third list of attributes are positive and integrate desirable traits for both men and women entrepreneurs and their gender integrative enterprises.

Our theorizing recognizes that the social order in which the entrepreneurial ecosystem is embedded is gendered, as well as how existing theories of entrepreneurship reconstitute and reconstruct this gendering (Ahl, 2002). Following socialist and Marxist feminist scholars, we acknowledge the problems

\section{Men's Entrepreneurship Model (negative attributes to retire)}

Profit-maximizing and nonsustainable (do not account for global climate change impacts, growing income inequality, systemic gender economic inequality and social problems that demand entrepreneurial solutions)

Competitive (zero sum game; cutthroat competition)

Economically exploitative of women's labor

Internalizing of socially constructed gender norms (prioritizing breadwinning and time on the business over time with family, even if they desire to spend more time with family)

Excluding of Other: homophilic behavior (only 4\% of equity funding goes to women; minorities and women are left out of networks, incubators; and accelerators; men have almost exclusively male mentors and networks)

\section{Women's Entrepreneurship Model (negative attributes to retire)}

Flexibility-maximizing (allowing time for caregiving, working from home, and spouse's career objectives)

Accommodating (reducing time spent on the business to support the family with their time, emotional support, energy)

Sabotaging of their own talent, potential, and sacrificial labor (delay launching and limiting growth of their own business ideas and ventures to support their spouses' paid work; by default doing all/most of the housework and caregiving without demanding equity in the home and collective support outside the home)

Internalizing of socially constructed gender norms (not seeking high-growth ventures/STEM fields and business/finance education) Depending on men to get ahead and fearing, avoiding, or sabotaging other women (women have mixed networks and more male mentors than female mentors)

\section{Gender Integrative Entrepreneurship Model (the gender-inclusive attributes to adopt)}

Value-maximizing to multiple stakeholders

Quality-of-life maximizing (strives to enhance happiness and collective well-being)

Collaborative (inclusive and attentive to all stakeholders, including paid and unpaid labor that supports the enterprise, social and community groups)

Collectively supported in a just and fair way (acknowledging and demanding collective support for caregiving responsibilities that is gender equitable, ideally state-supported full-day infant through tertiary education that are operated by well-qualified, well-compensated male and female professional educators)

Figure 1. Model of Gender Integrative Approach to Entrepreneurship 
with the split of the private from the public, which occurred under industrialization and adoption of modern capitalist economic systems, when mostly men went to the factories, offices, and boardrooms and women mostly stayed at home or labored in unpaid and underpaid support roles (see Acker, 1990). In the new knowledge economy, the assumptions of the industrial era still remain in our collective subconscious, particularly among the generation of powerful gatekeepers in the entrepreneurial ecosystem (largely middle- to upper-class white males). Stereotypes, idealizations, and assumptions still reflect a male breadwinner and a stay-at-home mom, regardless of this family model being outmoded.

Placing primary responsibility for raising children and caring for the household on women effectively takes them out of the market for opportunitydriven, growth-oriented venture creation and management. As a remedy for this structural barrier, we propose a dual solution: first, socialization of the "private" sphere labor in the form of publicly supported child care and full-day education and second, gender equality in the distribution of household labor. Further, these structural gender inequalities can be broken down by scholars illuminating how the historical and cultural positioning of women as being primarily responsible for undervalued, unpaid, and underpaid domestic and caregiving work creates barriers to gender equality in entrepreneurship. In addition, researchers who interview individual entrepreneurs should end the practice of querying only women entrepreneurs about their "work-life balance" and family issues (Ahl, 2002).

As our third point, we further a gender integrative conceptualization of entrepreneurship that challenges the assumptions that the main driver of entrepreneurs and entrepreneurship activity is wealth creation and accumulation. In effect, we suggest that a holistic understanding of entrepreneurship does not decouple public and private spheres or profit-seeking versus social aims. A gender integrative view would celebrate the entrepreneur who primarily seeks social justice, value creation for diverse stakeholders, and/or well-being and happiness over profits. Moreover, our approach problematizes assumptions behind the expressed motivations of women entrepreneurs to found "lifestyle businesses" to balance work and family, while men express motivations to seek wealth in founding businesses (DeMartino and Barbato, 2003). If our society expected both men and women to share family responsibilities equitably, then we believe these gender differences in expressed reasons for starting a business might be eliminated, with men equally expressing motivations of flexibility and ability to balance a career with their family obligations and women equally expressing opportunity-driven motives.

Drawing on radical feminism, we suggest that feminized organizational structures promise to bring higher performance and greater innovation in complex, uncertain, and rapidly changing environments. Female founders have been found to exhibit a preference for more egalitarian and less hierarchical organizational structures (Cliff, 1998) and flatter organizational structures offer greater autonomy to workers. This might lead to higher performance in fields demanding greater cognitive skill and complex and creative problem solving (Pink, 2010). The alternative model we propose builds on feminist organizational practices to call for a new generation of enterprises that are built to meet the 21 st-century need for much greater inclusion, diversity, flexibility, and sustainability. The 20th-century industrial firm arose out of an entrepreneurial ecosystem that overwhelmingly privileges masculine ideal-type ways of identifying opportunities, harnessing resources, building and running organizations, and prioritizing shareholders over other stakeholders. The traits we list as gender integrative in Figure 1 push the field toward valuing entrepreneurs and enterprises that are critical to adopt for achieving higher performance in terms of sustainability and collective wellbeing.

\section{Empirical Support for a Gender Integrative Approach}

Recent empirical work suggests support for and value in our gender integrative conceptualization, particularly in respect to gender-neutral imagery, language, and representation of what constitutes the ideal-type entrepreneur and entrepreneurial qualities or competencies. Applying a stereotype threat perspective to the interpretation of results from two controlled experiments in Turkey and the United States, Gupta, Goktan, and Gunay (2014) found that both "men and women evaluated business opportunity equally favorably when entrepreneurs were described using gender-neutral attributes, [but that] gender differences in opportunity evaluation were exacerbated when entrepreneurship was linked to masculine stereotypical information, and reversed in favor of women when entrepreneurship was linked to feminine stereotypical information" (Gupta et al., 2014: 273). In a psychology lab experiment, Baron, Markman, and Hirsa (2001) found that with images of women (shown to both men and women), women were rated as more attractive when they were described as entrepreneurs than when they were described as managers, although they were also rated as less feminine. Implying that individual women re- 
ceive an "entrepreneurial boost" in the form of a masculine-based professional competency gain and/ or a minimalization of their "feminine liability" in the business world, the authors conclude that "women may benefit to a greater extent than men from assuming entrepreneurial roles, at least with respect to how they are perceived by persons unacquainted with them" (Baron et al., 2001: 926). These empirical findings lend support to the notion that gendered "perceptions of entrepreneurs often influence important decisions about them by venture capitalists, potential customers, prospective employees, and others, and such perceptions may strongly affect entrepreneurs success in establishing new ventures" (Baron et al. 2001: 928; Shane and Venkataraman, 2000).

As a powerful antidote to gender bias in entrepreneurship, Gupta, Turban, and Bhawe (2008) draw on stereotype activation theory (SAT) to suggest that stereotype nullification (i.e., purposefully "associating entrepreneurship with gender-neutral characteristics) may eliminate the gender gap in entrepreneurial intentions" (Gupta et al., 2008: 1055; see also Ahl, 2006; Gupta et al., 2005). Scholars note that such stereotype nullification can reduce "cognitive load" arising from gender stereotyping and that the nullification of gender stereotyping is particularly critical given its pervasiveness (Gupta et al., 2008; Smith and White, 2002; Smith and Johnson, 2006). These theoretically grounded arguments and empirical findings align with our claims and suggestions. Specifically, active nullification of the ubiquitous masculinized stereotyping with regard to entrepreneurship through explicitly describing entrepreneurs and entrepreneurial traits and activities as stereotypically feminine on balance, and/or gender neutral promises to collapse the well-documented gender gap in entrepreneurship.

These gender neutralizing interventions are most critical to high-growth entrepreneurship, where Sweida and Reichard (2013) argue women face a dual stereotype: first, specific industries hold embedded masculine stereotypes and second, entrepreneurship itself is highly masculinized. These authors also suggest that, "by decreasing the masculine stereotype -related barriers associated with high-growth entrepreneurship and increasing women's high-growth entrepreneurship self-efficacy, it should be possible to increase women's intention to engage in highgrowth venture creation" (Sweida and Reichard, 2013: 296). As feminist scholars working in academia, we have a role to play in ensuring that gender equality is enacted through our research.

Following Heilman (2001) and Gupta et al. (2008), we implore professionals in academia to (1) openly discuss existing, widespread gender stereotypes, (2) adopt gender-neutral language, (3) use gender-integrative case studies and examples, and (4) provide as many female as male role models, mentors, and support providers (e.g., guest speakers, entrepreneurs-in-residence, advisory board members). The field of entrepreneurship itself is hamstrung by a "gendered infrastructure," which includes relegation of the topic of women's entrepreneurship and gender and entrepreneurship to separate conferences, tracks, and special issues of journals (De Bruin et al., 2006, 2007; Jennings and Brush, 2013). No work that we can find addresses the need to fix the vast gender gap in the study of academia in entrepreneurship and its power structures (such as the full and endowed professorships, entrepreneurship center executive directors, and on the boards of journals and entrepreneurship associations), which should help to mitigate what constitutes acceptable epistemological and methodological approaches to the study of entrepreneurship and what is in itself valued in the field, as manifested by what work is accepted at the top journals in entrepreneurship.

As has been noted, only a few articles have been published in the top entrepreneurship journals that apply a feminist theoretical approach and/or that treat gender as a lens as opposed to a variable (Brush et al., 2009). In addition, as Jennings and Brush (2013) ). Note, the financial investment in the study of gender and entrepreneurship is woefully miniscule compared to other tracks of study despite the rise of women entrepreneurs. Our engagement with these ongoing concerns as feminist scholars studying entrepreneurship gives way to critique and new directions for research and action, which we outline next.

\section{Discussion: Contributions of Our Framework and Some Limitations}

The approach we propose has the potential to be both an explanatory model for why the entrepreneurial world is as it is, as well as a visionary model of the way the entrepreneurial world might be (i.e., based on gender equality and inclusion with improved outcomes overall). Based on our analyses, key takeaways include recognition and valuing of feminist engagement with business and greater attention to (intersectional) differences among women entrepreneurs. For example, inclusion and integration of different feminist organizational structures based on a model of decentralization, fluidity, flatness, democracy, equality, and consensus can bring greater levels of innovation, flexibility and respon- 
siveness to market opportunities (Buzzanell and D’Enbeau, 2013; Ferguson, 1985; Ferree and Martin, 1995; Iannello, 1992; Thomas, 1999).

Further, our work challenges the dominant normative and perceptive association of men with the societally constructed public realm of breadwinning and paid economic responsibilities. This is the first step to increasing the normative support and cultural desirability of women as entrepreneurs (Baughn et al., 2006; De Bruin et al., 2007; Langowitz and Minniti, 2007), and critical, we argue, for men (and women) to be fully engaged supporters of women entrepreneurs as their partners, spouses, advocates, investors, employees, managers, and lenders. Our approach illuminates and explains how societally constructed gender norms interact with gendered professional norms of entrepreneurship, and how such "double binds" might be navigated in practice (Jamieson, 1995). In addition, we address an important-and to our knowledge heretofore unacknowledged point in the field of entrepreneurship-that individual men are harmed by the status quo, in the form of experiencing greater work-life conflict (Aumann et al., 2011). Even though our approach acknowledges both male and female entrepreneurs as part of the discussion on gender, we acknowledge that near-term solutions given the state of the world as it is might require adoption of radical feminist interventions.

Early successes among emerging programs of women-only angel investor networks, incubators, accelerator programs, pitch competitions, and networking events suggest adoption of such a radical feminist approach is in order (e.g., Springboard Enterprises, Astia, WIN Lab, Women Innovate Mobile, We Own It Summit, Women 2.0; LaunchPad2X; Count Me In). While this solution may produce desirable and tangible gains for some women, there still remains a tension between profit seeking and feminism. To this end, we engage socialist and Marxist theorizing about the possibility of socializing currently undervalued and underpaid caregiving labor, while also acknowledging the inherent conflict between Marxist-socialist and free-market capitalist ideologies. For these reasons, private solutions need to complement public and political action, which we outline next.

Based on our gender integrative approach, we suggest that educational solutions and governmental programs drop gender-neutral assumptions, and focus on addressing demand-side problems of individual women. These problems stem from societally constructed gender norms, implicit biases, and subjective perceptions of women's weaker personal entrepreneurial abilities. Programs need to be designed to address these gendered self-efficacy and self- confidence gaps effectively (Langowitz and Minniti, 2007; Wilson et al., 2007). The solutions, however, must not stop at the individual entrepreneur.

Significant structural barriers remain, including gendered division of labor and domestic responsibilities that can be addressed by national equality programs designed to close the gender gap in equity funding and growth trajectories (Alsos et al., 2006). Supply-side remedies are also needed. The pipeline to equity finance is heavily gendered (Carter et al., 2003; Marlow and Patton, 2005) including participation in accelerator and incubation programs, where approximately 95 percent of participants and directors are male (Clark Muntean and Özkazanç-Pan, 2014). Government policies should directly address the inequities in equity finance, its pipeline and networks, and open up these resources for women. The first step is requiring public and publicly subsidized organizations to collect and make publicly available data on the percentage of women participants and businesses recruited, selected, assisted, and funded, and to pressure privately held institutions to report the share of women-owned businesses they assist and finance (Alsos et al., 2006).

Finally, consciousness raising about the insidious but rampant cultural and societally embedded psychological and sociological barriers for women entrepreneurs needs to happen. The entrepreneurial ecosystem is likely fraught with gender schematic thinking, stereotype threat, and conflicts between gender norms and occupational norms that result in the perfect storm holding back women founders from high-stakes venture capital and high-tech/highgrowth entrepreneurship (Antony, 2012). In the hypercompetitive and hypermasculine marketplace, explicitly feminist organizations may need to be more active in the realms of venture capital, business incubation and acceleration programs, and angel investment networks to effect social change through the communication of values, framing of problems, and creation of solidarity that underscores unwavering commitment to gender equity in entrepreneurial outcomes (Buzzanell and D'Enbeau, 2013)

While these are positive attributions and possibilities associated with our model, we also recognize that our framework can also potentially perpetuate stereotypes as women-only entrepreneurial support organizations and spaces become an established norm rather than challenge or change the status quo. It is also important to acknowledge that many of our assumptions are based on heteronormative ideas and a much more complex approach to the study of entrepreneurship would require an intersectional analysis focusing on relations of difference across gender, race, class, ethnicity, sexual orientation, and so forth. Equally, our calls for engaging in social justice and 
gender equality in entrepreneurship research and practice may not yield emancipatory entrepreneurship for women and men of the Global South, LGBTQI individuals and others occupying structurally oppressed positions in society. As feminist scholars working in the field of entrepreneurship, we note that much work remains to be completed with regard to theorizing and research that not only rec- ognizes gender as an organizing principle of entrepreneurship but also heeds the call toward gender equality in the enactment of entrepreneurship. In this regard, we offer the gender integrative approach as a first step in voicing and redirecting underlying assumptions guiding “women's entrepreneurship" research.

\section{References}

Achtenhagen, L., and Welter, F. 2007. Media discourse in entrepreneurship research. Handbook of Qualitative Methods in Entrepreneurship Research : 193-215.

Acker, J. 1990. Hierarchies, jobs, bodies: A theory of gendered organizations. Gender \& Society 4(2): 139-158.

Ahl, H.J. 2002. The making of the female entrepreneur: a discourse analysis of research texts on women's entrepreneurship. Jönköping International Business School, Jönköping University, Sweden.

Ahl, H.J. 2004. The scientific reproduction of gender inequality: A discourse analysis of research texts on women's entrepreneurship. Stockholm: Liber AB.

Ahl, H.J. 2006. Why research on women entrepreneurs needs new directions. Entrepreneurship Theory and Practice, 30(5): 595-621.

Ahl, H.J., and Nelson, T. 2010. Moving forward: institutional perspectives on gender and entrepreneurship. International Journal of Gender and Entrepreneurship, 2(1), 5-9.

Ahl, H.J., and Marlow, S. 2012. Exploring the dynamics of gender, feminism and entrepreneurship: advancing debate to escape a dead end? Organization 19(5): 544-562.

Alsos G.A., Isaksen E.J. and Ljunggren E. 2006. New venture financing and subsequent business growth in men- and women-led businesses. Entrepreneurship Theory and Practice 30(5): 667-686.

Anna, A.L., Chandler, G.N., Jansen, E., and Mero N.P. 2000. Women business owners in traditional and non-traditional industries. Journal of Business Venturing 15(3): 279-303.

Antony, L. 2012. Different voices or perfect storm: Why are there so few women in philosophy? Journal of Social Philosophy 43(3): 227255.

Aumann, K., Galinsky, E., and Matos, K. 2011. The new male mystique. Families and Work Institute.

Baron, R.A., Markman, G.D., and Hirsa, A. 2001. Perceptions of women and men as entrepreneurs: Evidence for differential effects of attributional augmenting. Journal of Applied Psychology 86(5): 923-929.

Baron, R.A., and Henry, R.A. 2011. Entrepreneurship: the Genesis of Organizations, Baron, R.A, in Zedeck, S. (Ed.), APA Handbook of Industrial and Organizational Psychology APA, Washington, DC, (1): 241-273.

Barker, D. K. (2014). Beyond women and economics: rereading “women's work.” Signs, 40(1).

Barrett, M. 2014. Women's oppression today: The Marxist/feminist encounter. Verso Books.

Baughn, C.C., Chua, B-L., and Neupert, K.E. 2006. The normative context for women's participation in entrepreneurship: A multicountry study. Entrepreneurship Theory and Practice 30(5): 687-708.

Bird, B., and Brush, C.G. 2002. A gendered perspective on organizational creation. Entrepreneurship Theory and Practice, 26(3): 41-65.

Bond, J., Galinsky, E., and Hill E. 2002. When Work Works: Summary of Families and Work Institute Research Findings. National Study of the Changing Workforce. Families and Work Institute: 1-13.

Bourne, K.A. 2006, January 1. In and out of balance: Women entrepreneurs and the gendered 'work' of work-family. University of Massachusetts Amherst, Amherst, MA.

Bourne, K.A. 2010. The paradox of gender equality: An entrepreneurial case study from Sweden. International Journal of Gender and Entrepreneurship (2): 10-26.

Bruni, A., Gherardi, S., and Poggio B. 2004. Entrepreneur-mentality, gender and the study of women entrepreneurs. Journal of Organizational Change Management 17(3): 256-268.

Brush C.G., de Bruin A. and Welter F. 2009. A gender-aware framework for women's entrepreneurship. International Journal of Gender and Entrepreneurship 1(1): 8-24.

Brush C.G. and Edelman L.F. 2000. Women entrepreneurs opportunities for database research. Databases for the Study of Entrepreneurship 4: 445-484. 
Butler J.E. (ed). 2003. New Perspectives on Women Entrepreneurs. Information Age Publishing: Greenwich, CT, A Volume in Research in Entrepreneurship and Management.

Buttner, E.H. 2001. Examining female entrepreneurs' management style: an application of a relational frame. Journal of Business Ethics 29 (3): 253-269.

Buzzanell, P.M., and, D'Enbeau S. 2013. Constructing a feminist organization's identity in a competitive marketplace: The intersection of ideology, image, and culture. Human Relations 66(11): 1447-1470.

Calás, M. B., and Smircich, L. 2006. From the 'Woman’s Point of View’ Ten Years Later: Towards a Feminist Organization Studies. In S.R. Clegg, C. Hardy, T. Lawrence, and W.R. Nord (Eds.), The Sage handbook of organization studies, Thousand Oaks, CA: Sage: $284-346$.

Calás, M.B., Smircich, L., and Bourne, K.A. 2007. Knowing Lisa? Feminist analyses of gender and entrepreneurship. Handbook on women in business and management, 78-105.

Calás M.B., Smircich, L., and Bourne, K.A. 2009. Extending the boundaries: Reframing 'entrepreneurship as social change' through feminist perspectives. Academy of Management Review 34(3): 552-569.

Carter, N., Brush, C., Greene, P., Gatewood, E., and Hart, M. 2003. Women entrepreneurs who break through to equity financing: the influence of human, social and financial capital. Venture Capital: an international journal of entrepreneurial finance, 5(1): 1-28.

Carter, N.M., and Williams, M.L. 2003. Comparing social feminism and liberal feminism. In New Perspectives on Women Entrepreneurs, Butler JE (ed). Information Age Publishing: Greenwich, CT: 25-50.

Chell, E., and Baines, S. 1998. Does gender affect business 'performance'? A study of microbusinesses in business services in the UK. Entrepreneurship \& Regional Development 10(2): 117-135.

Clark Muntean, S., and Özkazanç-Pan, B. 2014. Social networking and technology-focused business incubators: A critical gender perspective. In Academy of Management Proceedings, 2014(1): 14177.

Cliff, J.E. 1998. Does one size fit all? exploring the relationship between attitudes towards growth, gender, and business size. Journal of Business Venturing 13(6): 523-542.

Cooper, M. 2000. Being the "go-to guy": Fatherhood, masculinity and the organization of work in Silicon Valley. Qualitative Sociology 23(4): 379-405.

De Bruin, A., Brush, C.G., and Welter, F. 2006. Introduction to the special issue: Towards building cumulative knowledge on women's entrepreneurship. Entrepreneurship Theory and Practice 30(5): 585-593.

De Bruin, A., Brush, C.G., and Welter, F. 2007. Advancing a framework for coherent research on women's entrepreneurship. Entrepreneurship Theory and Practice 31(3): 323-339.

DeMartino, R., and Barbato, R. 2003. Differences between women and men MBA entrepreneurs: Exploring family flexibility and wealth creation as career motivators. Journal of Business Venturing 18(6): 815-832.

DeTienne, D.R., and Chandler, G.N. 2007. The role of gender in opportunity identification. Entrepreneurship Theory and Practice 31(3): 365386.

Eddleston, K. A., and Powell, G. N. 2012. Nurturing entrepreneurs' work-family balance: A gendered perspective. Entrepreneurship Theory and Practice, 36(3), 513-541.

Ferguson, K.E. 1985. The Feminist Case Against Bureaucracy. Temple University Press.

Ferree, M.M., and Martin, P.Y. 1995. Doing the work of the movement: Feminist organizations. In Feminist organizations: Harvest of the new women's movement, Ferree, M.M., and Martin, P.Y. (eds). Temple University Press.

Fischer, E.M., Reuber, A.R., and Dyke, L.S. 1993. A theoretical overview and extension of research on sex, gender, and entrepreneurship. Journal of Business Venturing 8(2): 151-168.

Freire, P. 1970/1990. Pedagogy of the oppressed. NY: Continuum.

Gibson-Graham, J. K. 1996. "The" End of Capitalism (as We Knew It): A Feminist Critique of Political Economy; with a New Introduction. University of Minnesota Press.

Godwin, L.N., Stevens, C.E., and Brenner, N.L. 2006. Forced to play by the rules? Theorizing how mixed-sex founding teams benefit women entrepreneurs in male-dominated contexts. Entrepreneurship Theory and Practice 30(5): 623-642.

Goffee, R., and Scase, R. 1983. Business ownership and women's subordination: A preliminary study of female proprietors. The Sociological Review 31(4): 625-648.

Greene, P.G., Hart, M.M., Gatewood, E.J., Brush, C.G., and Carter, N.M. 2003. Women entrepreneurs: Moving front and center: An overview of research and theory. USASBE White Papers, United States Association for Small Business and Entrepreneurship. 
Greer, M. Greene, P.G., and Butler, J.E. 2003. Feminist Theory and the Study of Entrepreneurship. In New Perspectives on Women Entrepreneurs, Research in Entrepreneurship and Management. Information Age Publishing: Greenwich, CT: 1-24.

Gupta, V.K., Turban, D.B., and Bhawe N.M. 2008. The effect of gender stereotype activation on entrepreneurial intentions. Journal of Applied Psychology 93(5): 1053-1061.

Gupta, V.K., Turban, D.B., Wasti, S.A., and Skdar, A. 2009. The role of gender stereotypes in perceptions of entrepreneurs and intentions to become an entrepreneur. Entrepreneurship Theory \& Practice 33 (2), 397-417.

Gupta, V.K., and Turban, D.B. 2012. Evaluation of new business ideas: Do gender stereotypes play a role? Journal of Managerial Issues 24: 14-156.

Gupta V.K., Goktan A.B., and Gunay G. 2014. Gender differences in evaluation of new business opportunity: A stereotype threat perspective. Journal of Business Venturing 29: 273-288.

Heilman, M. E. 2001. Description and prescription: How gender stereotypes prevent women's ascent up the organizational ladder. Journal of Social Issues 57(4): 657-674.

Hoskyns, C., and Rai, S. M. 2007. Recasting the global political economy: Counting women's unpaid work. New Political Economy, 12(3): $297-317$.

Hurley, A.E. 1999. Incorporating feminist theories into sociological theories of entrepreneurship. Women in Management Review 14(2): 5462.

Iannello, K. 1992. Decisions Without Hierarchy: Feminist Interventions in Organization Theory and Practice. Routledge.

Jamieson, K. H. 1995. Beyond the Double Bind: Women and Leadership. Oxford University Press.

Jennings, J. E., and Brush, C. G. 2013. Research on women entrepreneurs: challenges to (and from) the broader entrepreneurship literature? The Academy of Management Annals 7(1): 663-715.

Langowitz, N., and Minniti, M. 2007. The entrepreneurial propensity of women. Entrepreneurship Theory and Practice 31(3): 341-364.

Marlow, S., and McAdam, M. 2013. Incubation or induction? Gendered identity work in the context of technology business incubation. Entrepreneurship Theory and Practice 39(4): 791-816.

Marlow, S., and Patton, D. 2005. All credit to men? Entrepreneurship, finance, and gender. Entrepreneurship Theory and practice, 29(6): 717735.

Mirchandani, K. 1999. Feminist insight on gendered work: New directions in research on women and entrepreneurship. Gender, $W$ ork \& Organization 6(4): 224-235.

Nagar, R., and Swarr, A.L. 2010. Transnational feminist praxis in Swarr, A.L. and Nagar, R. (Eds.) Critical transnational feminist praxis.NY: Suny Press: 1-22.

Özkazanç-Pan, B. 2014. Postcolonial feminist analysis of high-technology entrepreneuring. International Journal of Entrepreneurial Behavior \& Research, 20(2), 155-172.

Pink, D.H. 2010. Drive: The surprising truth about what motivates us. Edinburgh: Canongate.

Robb, A.M., and Watson, J. 2012. Gender differences in firm performance: Evidence from new ventures in the United States. Journal of Business Venturing 27(5): 544-558.

Roberts, P., and Johnson, S. 2013. Data-Driven Insights about Impact Entrepreneurs and Accelerators: 2013 Mid-Year Data Summary. Aspen Network of Development Entrepreneurs, Washington, D.C. 1-8.

Servon, L.J. 1996. Microenterprise programs and women: Entrepreneurship as individual empowerment. Journal of Developmental Entrepreneurship 1(1): 31-55.

Shane, S., and Venkataraman, S. 2000. The promise of entrepreneurship as a field of research. Academy of Management Review 25(1): 217226.

Smircich, L., and Cálas, M.B.L. 1992. Using the 'F' word: Feminist theories and the social consequences of organizational research. In Gendering organizational analysis, Mills AJ, Tancred P (eds). Sage: Newbery Park, CA: 222-234.

Smith, J. L., and White, P. H. 2002. An examination of implicitly activated, explicitly activated, and nullified stereotypes on mathematical performance: It's not just a woman's issue. Sex Roles 47(3-4): 179-191.

Smith, J. L., and Johnson, C. S. 2006. A stereotype boost or choking under pressure? Positive gender stereotypes and men who are low in domain identification. Basic and Applied Social Psychology 28(1): 51-63.

Sonfield, M.C. n.d. Strategic responses to the decline and/or elimination of government set-aside programs for minority and womenowned businesses. Small Business Institute Directors Association. 
Stanley, L. (Ed.). 2013. Feminist praxis: Research, theory and epistemology in feminist sociology. Routledge.

Sullivan, D.M., and Meek, W.R. 2012. Gender and entrepreneurship: a review and process model. Journal of Managerial Psychology 27(5-6): 428-458.

Sweida, G.L., and Reichard, R.J. 2013. Gender stereotype effects on entrepreneurial self-efficacy and high-growth entrepreneurial intention. Journal of Small Business and Enterprise Development 20(2): 296-313.

Thebaud, S. 2010, October 20. Institutions, Cultural Beliefs and the Maintenance of Gender Inequality in Entrepreneurship Across Industrialized Nations. Cornell University, Ithaca, NY.

Thomas, J.E. 1999. "Everything about US is Feminist": The Significance of Ideology in Organizational Change. Gender and Society 13(1): $101-119$.

Toegel, G. February 18, 2011. "Disappointing statistics, positive outlook," Forbes magazine, online version. http:// www.forbes.com/2011/02/18/women-business-management-forbes-woman-leadership-corporate-boards.html. Accessed July 21, 2015.

Vroom, V.H. 1964. Work and motivation. New York: Wiley, 1964. 331 p. Pittsburgh, PA: Carnegie Institute of Technology.

Watson, J. 2002. Comparing the performance of male- and female-controlled businesses: Relating outputs to inputs. Entrepreneurship Theory and Practice 26(3): 91-100.

Wilson, F., Kickul, J., and Marlino D. 2007. Gender, entrepreneurial self-efficacy, and entrepreneurial career intentions: Implications for entrepreneurship Education. Entrepreneurship Theory and Practice 31(3): 387-406.

\section{About the Authors}

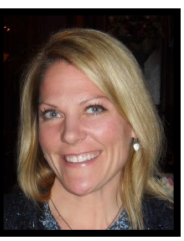

Susan Clark MunTEAN (smuntean@unca.edu) is an Assistant Professor of Management at the University of North Carolina at Asheville. Prior teaching positions include Ball State University and the London School of Economics. She holds a Ph.D. from the University of California, San Diego and an M.B.A. from the University of Oregon.

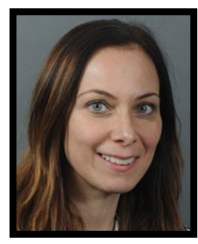

BANU ÖZKazANÇ-PAN (Banu.ozkazanc-pan@umb.edu) is an Assistant Professor of Management and fellow at the Entrepreneurship Center at the College of Management, University of Massachusetts Boston. Her research examines gender, diversity, and inclusion issues in start-up ecosystems and hightechnology ventures as well as in international entrepreneurship and management contexts. 